\title{
硫酸メチレンと加圧一酸化炭素によるグリコール酸 メチル合成反応の速度論的研究
}

\author{
（1974 年 9 月 30 日 受 理）
}

柳ヶ瀬，昭・杉田信之・工藤 清・竹崎嘉 真*

非プロトン溶媒下において硫酸メチレンと加圧一酸化炭素からグリコール酸メチルが生成することを 見いだし，この反応を速度論的に検討した。反応速度は一酸化炭素圧の一次，硫酸メチレン初濃度のほ ぼ一次であり，硫酸メチレンは熱溶媒中に打いて（i ）で示される分解平衡の状態にあることがわかっ た。

これらの結果から下記の反応機構を設定し速度式を誘導した。

$$
\begin{aligned}
& \mathrm{CH}_{2}\left\langle\begin{array}{l}
\mathrm{OSO}_{2} \mathrm{O} \\
\mathrm{OSO}_{2} \mathrm{O}
\end{array}\right\rangle \mathrm{CH}_{2} \stackrel{K_{1}}{\rightleftarrows} 2\left[\mathrm{CH}_{2} \mathrm{OSO}_{3}\right] \stackrel{K_{2}}{\rightleftarrows} 2 \mathrm{HCHO}(d)+2 \mathrm{SO}_{3}(d) \\
& {\left[\mathrm{CH}_{2} \mathrm{OSO}_{3}\right]+\mathrm{CO}(d) \stackrel{k}{\longrightarrow}\left[\mathrm{CH}_{2}(\mathrm{CO}) \mathrm{OSO}_{3}\right]} \\
& {\left[\mathrm{CH}_{2}(\mathrm{CO}) \mathrm{OSO}_{3}\right]+2 \mathrm{CH}_{3} \mathrm{OH} \stackrel{\text { 系 }}{\longrightarrow} \mathrm{CH}_{2}(\mathrm{OH}) \mathrm{COOCH}_{3}+\mathrm{CH}_{3} \mathrm{OSO}_{3} \mathrm{H}}
\end{aligned}
$$

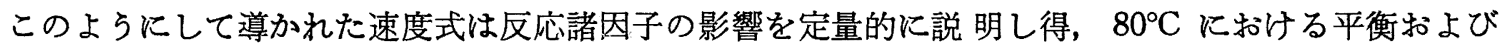
速度定数として， $K_{1}=1.22 \times 10^{-2} K_{2}=5.6 \times 10^{-3}, k=6.05 \mathrm{~min}^{-1} 1,2-$ ジクロロエタン，テトラクロロ エチレンに対する一酸化炭素の溶解に関する Henry 定数として, $H_{\mathrm{EDC}}^{\mathrm{CO}}=6.8 \times 10^{-4} \mathrm{~kg}^{-1} \cdot \mathrm{cm}^{2}, H_{\mathrm{TCE}}^{\mathrm{CO}}=$ $8.4 \times 10^{-4} \mathrm{~kg}^{-1} \cdot \mathrm{cm}^{2}$ ，また本反応の見かけの活性化エネルギーとして $28.9 \mathrm{kcal} \cdot \mathrm{mol}^{-1}$ を得た。

さらに本反応を 1,2-ジクロロエタン，テトラクロロエチレンの混合溶媒中で行ない誘電率と反応速 度との関係を検討し，本反応は双極子間の二分子反応であることを明らかにした。

\section{1 緒 言}

加圧一酸化炭素を用いるグリコール酸の合成法は, Loder ら による無機酸，Lewis 酸を触媒とする方法があるが，一酸化炭 素圧䄪 $1000 \mathrm{~atm}$ ，反応温度 $150 \sim 200^{\circ} \mathrm{C}$ と苛酷な条件を必要と し，かつ速度論的報文として岡本 ${ }^{2}$ の行なった希硫酸水中に扣け る反応に関するものがあるにすぎない。

著者らはグリコール酸メチル合成反応を発煙硫酸中で行ない, 非常に温和な条件下で進行することを見いたした。この反応の中 間体の一つと考えられる硫酸メチレン（以下 MS と略記する）に ついて，加圧一酸化炭素との反応を非プロトン性溶媒下で速度論 的実験を行ない, 実験結果を満足する速度式を誘導し，反応機構 を推定し得たので以下報告する。

\section{2 実験法}

\section{1 試 薬}

原料の MS は Baker ら ${ }^{3)}$ の方法により合成し使用した。 溶媒の 1,2-ジクロロェタン（以下 EDC と略記する），テトラ

* 京都大学化学研究所, 611 宇治市五ヶ庄

1) D. J. Loder, U. S. P., 2, 152, 852(1939).

2）岡本暢也, 工化, 58, 201(1955).

3) W. Baker, F. B. Field, J. Chem. Soc., 1932, 86.
クロロエチレン（以下 TCE と略記する）は炭酸ナトリウムで脱 酸処理後, 蒸留の上使用した。

一酸化炭素は熱硫酸によるキ酸の分解により製造し，純度 $98 \%$ 以上のものを使用した。

\section{2 装置・操作}

反応容器は内容積約 $300 \mathrm{ml}$ の抜き出しパイプを備えた電磁カ キマゼ式ステンレス製オートクレーブを使用した。このオートク レーブに所定量の原料, 溶媒を充テンし, 一酸化炭素でオートク レーブ中の空気をパージし，かきまぜながら電気炬により約 70 分間で所定温度に昇温後，一酸化炭素を所定圧まで圧入し，その 時点を反応開始点とした。所定時間ごとに反応液を抜き出し分析 試料とし，反応液の抜き出しにとすなら王降下は，ただちに一酸 化炭素を補給して，定圧下で反応を行なった。

また，パラホルムアルデヒドを熱分解し， EDC にホルムアルデ ヒドガスとして吸収させ，所定濃度の EDC-ホルムアルデヒド溶 液を調整した。同様に, 発煙硫酸を蒸留して得た $\mathrm{SO}_{3}$ を $\mathrm{EDC} に$ 吸収させ $\mathrm{EDC}^{-\mathrm{SO}_{3}}$ 溶液を調整した。

\section{3 分 析}

2.3.1 生成物の確認: 反応生成物を純水で回収し, 水酸化ハ

リウム・炭酸バリウムにより硫酸根を除去し，水溶性バリウム㙁 を陽イオン交換樹脂 I. R. 120 で陽イオン交換を行ない，水酸化 カルシウムにより酸性生成物をカルシウム塩として採取した。こ 
Table 1 Identification of the product

\begin{tabular}{|c|c|c|}
\hline & Product & Authentic sample \\
\hline IR & $\begin{array}{ll}\nu_{\mathrm{CO}} & 1580 \mathrm{~cm}^{-1} \\
\nu_{\mathrm{OH}} & 3300 \mathrm{~cm}^{-1}\end{array}$ & $\begin{array}{l}\nu_{\mathrm{CO}} 1580 \mathrm{~cm}^{-1} \\
\nu_{\mathrm{OH}} 3300 \mathrm{~cm}^{-1}\end{array}$ \\
\hline M. W. & 190.5 (calc. 190$)$ & \\
\hline $\begin{array}{l}\text { Spot test }(2,7 \text {-Dihydroxynaphthalene) } \\
\text { (Chromatropic acid) } \\
\text { G. C. (PEG } 20 \mathrm{M} 138^{\circ} \mathrm{C} \mathrm{N} \mathrm{N}_{2} 25 \mathrm{ml} / \mathrm{min} \text { ) Ret. time } \\
\text { (Porapac Q } 180^{\circ} \mathrm{C} \mathrm{N} \mathrm{N}_{2} \text { carrier) Ret. time }\end{array}$ & $\begin{array}{c}+ \\
+ \\
1 \mathrm{~min} 40 \mathrm{sec} \\
5 \mathrm{~min} 58 \mathrm{sec}\end{array}$ & $\begin{array}{c}+ \\
+ \\
1 \mathrm{~min} 40 \mathrm{sec} \\
5 \mathrm{~min} 58 \mathrm{sec}\end{array}$ \\
\hline
\end{tabular}

の塩について IR, 分子量測定, スポットテスト4)，ガスクロマト グラフィーによる同定試験を行ない表 1 亿示す結果を得, 有機酸 生成物がグリコール酸のみであることを確認した。なおガスク口 マトグラブィーによる同定は，カルシウム塩を塩酸酸性下でエー テル抽出し：メチルエステル化して行なった。

2.3.2 定 量 法: 反応生成物を 30 分以上熱水浴中でメチルェ ステル化を行なえば完全にエステル化が進行することを確認の上, 所定の反応時間ごとに抜き出しパイプより反応液を氷冷したメタ ノール中に回収して，熱水浴中で 30 分以上還流し生成するグリ コール酸メチルエステル（以下 GAM と略記する）をガスクロマ トグラフィー（PEG $20 \mathrm{M}$ カラム）により定量した。

なお，反応開始点に和ける GAM 生成量は充テン MS に対して $0.7 \%$ 以下であったので無視した。

\section{3 実 験 結 果}

\section{1 予備実験}

3.1 .1 溶媒の選択 : 発煙硫酸中にホルムアルデヒド対 $\mathrm{SO}_{3}$ が 1 対 1 となるようパラホルムアルデヒドを充テンし，一酸化炭素 と反応させ表 2 の結果を得た。一酸化炭素圧 $173 \mathrm{~kg} \cdot \mathrm{cm}^{-2}$ 反応 温度 $40^{\circ} \mathrm{C}$ といら非常に温和な条件下です高収率のグリコール酸

Table 2 Reaction in the oleum Conditions

\begin{tabular}{lccccc}
\hline $\begin{array}{c}\text { Oleum } \\
(\mathrm{wt})\end{array}$ & $\begin{array}{c}\text { Charged } \\
\text { HCHO } \\
(\mathrm{mol})\end{array}$ & $\begin{array}{c}P_{\mathrm{CO}} \\
(\mathrm{kg} \cdot \\
\left.\mathrm{cm}^{-2}\right)\end{array}$ & $\begin{array}{c}\text { Time } \\
(\mathrm{min})\end{array}$ & $\begin{array}{c}\text { Temp. } \\
\left({ }^{\circ} \mathrm{C}\right)\end{array}$ & $\begin{array}{c}\text { Analysis } \\
\text { glycolic acid } \\
(\mathrm{mol} \%)\end{array}$ \\
\hline 32.10 & 0.173 & 163 & 50 & 75 & $99.7^{a)}$ \\
35.00 & 0.350 & 163 & 135 & 60 & $\left.90.5^{b}\right)$ \\
6.22 & 0.051 & 173 & 30 & 40 & 81.1 \\
6.22 & 0.050 & 173 & 10 & 40 & 68.3
\end{tabular}

a) : Absorved CO : $97.7 \mathrm{~mol} \%$.

b) Residual $\mathrm{HCHO}: 10.8 \mathrm{~mol} \%$.

Table 3 Reaction in several solvents Conditions

\begin{tabular}{cccccc}
\hline Solvent & $\begin{array}{c}P_{\mathrm{CO}} \\
(\mathrm{kg} \cdot \\
\left.\mathrm{cm}^{-2}\right)\end{array}$ & $\begin{array}{c}\text { Time } \\
(\mathrm{min})\end{array}$ & $\begin{array}{c}\text { Temp. } \\
\left({ }^{\circ} \mathrm{C}\right)\end{array}$ & $\begin{array}{c}\left.L_{0}{ }^{a}\right) \\
\times 10^{2}\end{array}$ & $\begin{array}{c}\mathrm{GAM}^{b)} \\
\left(\mathrm{mol}^{b}\right)\end{array}$ \\
\hline EDC & 29 & 120 & 80 & 1.05 & 120.0 \\
Butyl chloride & 160 & 180 & 80 & 0.356 & 40.2 \\
Chlorobenzene & 314 & 180 & 80 & 0.492 & 27.5
\end{tabular}

a) $L_{0}:$ Initial conc. of $\mathrm{MS}=\frac{\text { Initial charge of MS (mol) }}{\text { Solvent (mol) }}$

b) $\frac{\text { Produced GAM (mol) }}{\text { Initial charge of MS (mol) }} \times 10^{2}$

4) F. Feigl, "Spot Tests in Organic Analysis", Elsevier Publishing Co. (1960) p. 377 .
が得られることがわかったが，発煙硫酸中では反応速度が大であ るため反応律速条件が得られなかった。ところが Baker ら 発煙硫酸中でホルムアルデヒドから MS が生成することを報告し ている。したがってMS がこの反応の中間体の一つと考えられた ので, MS を別途合成し，種々の非プロトン性溶媒中（EDC，ク ロロベンゼン，ブチルクロリドでの MS，と一酸化炭素との反応を 試みた。その結果, 表 3 のように EDC が本反応の良溶媒と判明 したので以下の速度論的研究ではこれを溶媒として採用した。

な拈，MS は二量体の形タをして拈り $1 \mathrm{~mol} の \mathrm{MS}$ から $2 \mathrm{~mol}$ の GAM が生成するので収率の計算に括いては，MS 基準の最高 収率は $200 \%$ となる。

3.1.2 溶媒に対する一酸化炭素の溶解度 : 解析のために必要 な溶媒 (EDC, TCE) に対する一酸化炭素の溶解度を検討し図 1 の結果を得た。本実験圧力範囲内に拈いては Henry の法則が成 立し， $\mathrm{EDC}, \mathrm{TCE}$ に対する Henry 定数として $H_{\mathrm{EDC}}^{\mathrm{CO}}=6.8 \times 10^{-4}$ $\mathrm{kg}^{-1} \cdot \mathrm{cm}^{2}, H_{\mathrm{TCE}}^{\mathrm{CO}}=8.4 \times 10^{-4} \mathrm{~kg}^{-1} \cdot \mathrm{cm}^{2}$ を得た。

3.1 .3 回転数の影響: $\mathrm{EDC}$ を溶媒とし反応温度 $80^{\circ} \mathrm{C}$, 一酸 化炭素圧 $29 \mathrm{~kg} \cdot \mathrm{cm}^{-2}$, 初充テン $\mathrm{MS}$ と溶媒とのモル比(以下 $L_{0}$ と略記する） 0.0105 として電磁カクハン翼の回転数を变化さ せた。 $1100 \mathrm{rpm}$ 以上では所定時間ごとの GAM 生成量は, かき まぜの影響を受けていなかったので, 以後の実験は回転数 1200 〜1500 rpm で行なった。

3.1 .4 物質收支: MS をメタノール中で還流すると, 定量的 にメチラールが生成することをガスクロマトグラフィー(PEG 20 M カラム) で確認し, 反応液中の未反応 MS をメチラールとして 定量した。その結果図 3 破線のグラフが得られ，対応する GAM 収率との和が 180〜190\% となり，ホルムアルデヒドについての

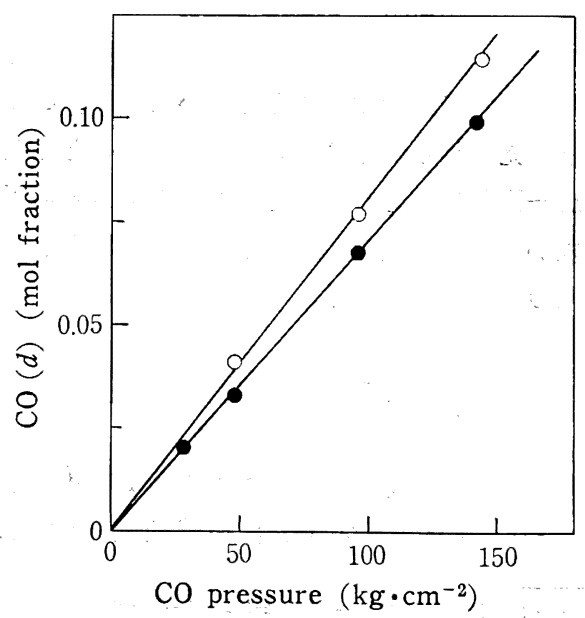

Fig. 1 CO solubility in EDC and TCE Solvent$O:$ TCE, $:$ EDC 


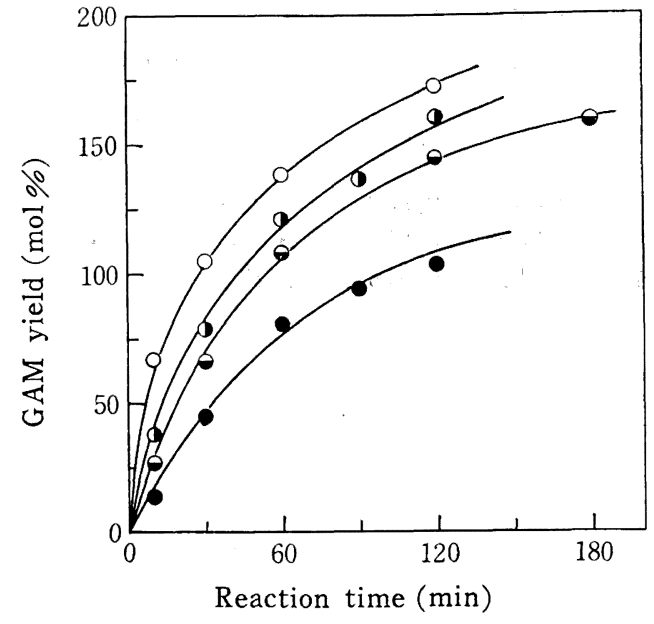

Fig. 2 Effect of $\mathrm{CO}$ pressure

Temp. $=80^{\circ} \mathrm{C}, L_{0}=0.0105$

$P_{\mathrm{CO}}\left(\mathrm{kg} \cdot \mathrm{cm}^{-2}\right)-$

$\bigcirc: 49, \quad: 29, \bigcirc: 19, \bigcirc: 9$

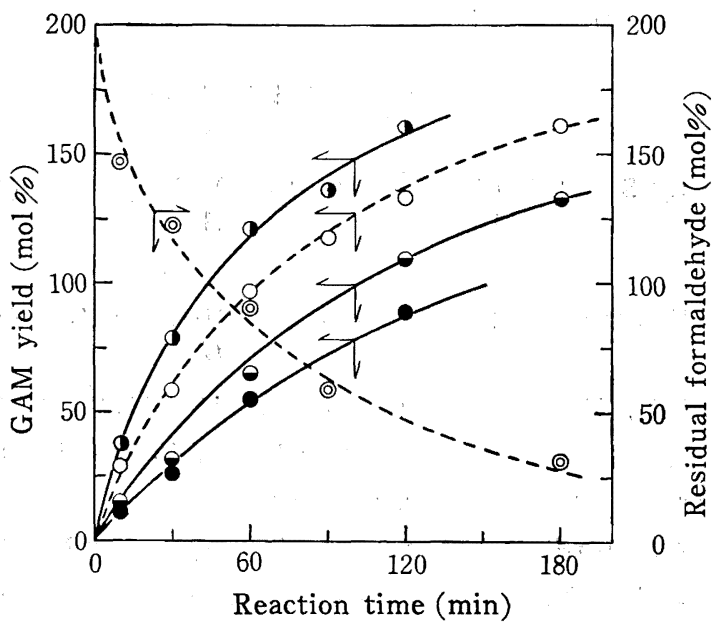

Fig. 3. Effect of initial charge mole ratio of MS Temp. $=80^{\circ} \mathrm{C}, P_{\mathrm{CO}}=29 \mathrm{~kg} \cdot \mathrm{cm}^{-2}$ $L_{0} \times 10^{3}$
: $10.5, \bigcirc: 6.98, \bigcirc: 3.48$,
$: 1.60$
(0) : Residual formaldehyde

物質収支は，ほぼ満足されていた。

また充テン MS $0.00995 \mathrm{~mol}$ から出発して GAM 収率 151.6 \%にいたったときの反応混合物を, “減圧蒸留により溶媒を留去 後, 水を加え 9 時間還流すると $0.0189 \mathrm{~mol}$ の硫酸が生じ, $\mathrm{SO}_{3}$ についての物質収支もほぼ満足されていた。

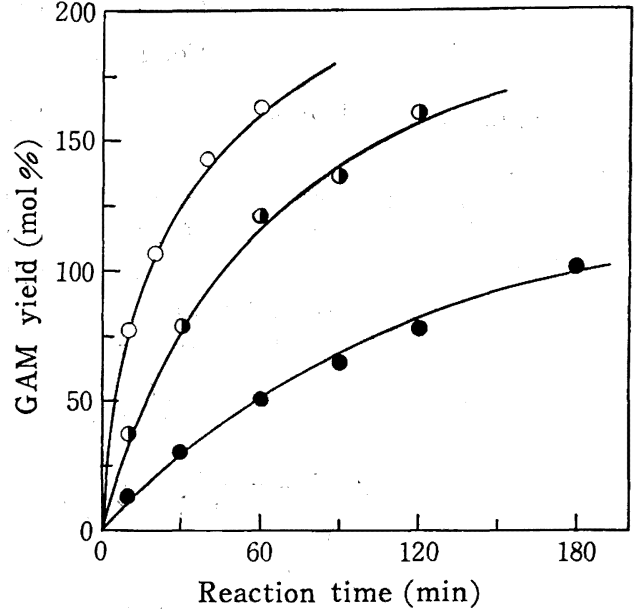

Fig. 4 Effect of temperature $P_{\mathrm{CO}}=29 \mathrm{~kg} \cdot \mathrm{cm}^{-2}, \quad L_{0}=0.0105$ Temp. $\left({ }^{\circ} \mathrm{C}\right)-$

$\bigcirc: 90, \quad: 80$,

$: 70$

\section{2 速度論的実験結果}

予備実験の結果から EDC を溶媒として本反応の速度におよ注 す一酸化炭素圧, 原料初濃度, 挌よび反応温度の影響について検 討を行ない図 2，3，4 に示す結果を得た。

\section{4 考察}

\subsection{MS の溶媒中における挙動}

速度論的解析を行ならにさき立って MS の熱溶媒下での挙動を 調べ以下の結果を得た。

室温に拈ける MS の分解の有無を調べるためベンゼン, DMSO にそれぞれ MSを溶解させ，ホルムアルデヒド， $\mathrm{SO}_{3}$ の検出を試 みたが，いずれも認められなかったので室温付近では分解が起こ っていないことが判明した。また凝固点降下法により MSの見か けの分子量を測定して表 4 の結果を得た。分子量が 140〜160で あることより MS 二量体 (M. W. 220) と MS 単量体 (M. W. 110) 間の平衡が存在することが明らかとなった。

つぎに高温での EDC 溶媒下の MS の挙動を知るため, MS と $\mathrm{EDC}$ をオートクレーブに充テンし，約 $80^{\circ} \mathrm{C}$ まで昇温して充テ ン量の一部を留出させたところ：ホルムアルデヒドと: $\mathrm{SO}_{3}$ が検 出され特の括のを分析し表 5 の結果を得た。このときのホルムア ルデヒド， $\mathrm{SO}_{3}$ の実測蒸気圧はどららす $0.17 \mathrm{~kg} \cdot \mathrm{cm}^{-2}$ であり； 充テン量に対しておの特のが気相にある割合は $2.8 \%$ たから無視 され，分析した值は溶媒に溶解しているすのであると見なされ る。このことは表 5 に拈いて空間率 $\left(V_{\mathrm{fre \theta}} / V_{\mathrm{vessel}}\right)$, 留出量を変

Table 4 Determination of the equilibrium constant $K_{1}$

\begin{tabular}{|c|c|c|c|c|c|c|c|c|}
\hline Solvent & $\begin{array}{l}\text { f. p. } \\
\left({ }^{\circ} \mathrm{C}\right)\end{array}$ & $\begin{array}{l}\Delta T_{\mathrm{f}}{ }^{a)} \\
\left({ }^{\circ} \mathrm{C}\right)\end{array}$ & $\mathrm{M} . \mathrm{W}^{\left.{ }^{b}\right)}$ & $\alpha^{c)}$ & $L_{0} \times 10^{3}$ & $D$ & $M$ & $K_{1}^{(d)} \times 10^{s}$ \\
\hline \multirow{3}{*}{ Benzene } & \multirow{3}{*}{5.3} & 0.036 & 136.8 & 0.608 & 0.341 & 0.392 & 1. 216 & 1.29 \\
\hline & & 0.018 & 128.3 & 0.712 & 0.159 & 0.288 & 1. 424 & 1.12 \\
\hline & & 0.048 & 140.6 & 0.565 & 0.467 & 0.435 & 1.130 & 1. 37 \\
\hline DMSO & 18.8 & $\begin{array}{l}0.090 \\
0.165\end{array}$ & $\begin{array}{l}148.7 \\
162.1\end{array}$ & $\begin{array}{l}0.479 \\
0.357\end{array}$ & $\begin{array}{l}\text { 1. } 160 \\
2.330\end{array}$ & $\begin{array}{l}0.521 \\
0.643\end{array}$ & $\begin{array}{l}0.958 \\
0.714\end{array}$ & 2.04 \\
\hline
\end{tabular}

a) Freezing point depression.

$b$ ) Apparent molecular weight.

c) Degree of dissociation.

d) $K_{1}=\frac{M^{2}}{D} L_{0}=\frac{(2 \alpha)^{2}}{1-\alpha} L_{0}$ 
Table 5 Determination of the equilibrium constant $K_{2}$

\begin{tabular}{|c|c|c|c|c|c|c|c|c|c|}
\hline \multicolumn{5}{|c|}{ Conditions } & \multicolumn{3}{|c|}{ Analysis } & \multicolumn{2}{|c|}{ Calculations } \\
\hline Solvent & $\begin{array}{c}\text { Temp. } \\
\left({ }^{\circ} \mathrm{C}\right)\end{array}$ & $L_{0} \times 10^{3}$ & $\frac{V_{\text {free }}}{V_{\text {vessel }}}$ & $\begin{array}{c}\left.\text { Distilled }^{a}\right) \\
\text { portion }\end{array}$ & $F / 2$ & $S / 2$ & Average & $M^{b)}$ & $\begin{array}{l}K_{2}{ }^{c)} \\
\times 10^{3}\end{array}$ \\
\hline \multirow{2}{*}{ EDC } & 85 & 6.31 & 0.177 & 0.146 & 0.830 & 0.855 & 0.843 & 0.250 & 5.2 \\
\hline & 86 & 6.31 & 0.410 & 0.0768 & 0.835 & 0.869 & 0.852 & 0.238 & 5.9 \\
\hline EDC-TCE $\left.^{d}\right)$ & 83 & 3.08 & 0.157 & 0.207 & 0.946 & 0.910 & 0.918 & 0.152 & 4.7 \\
\hline
\end{tabular}

a) $\frac{\text { Distilled (gr) }}{\mathrm{MS}(\mathrm{gr})+\text { Solvent (gr) }}$

b) $K_{1}=\frac{M^{2}}{D} L_{0} \quad D+\frac{M}{2}+\frac{S}{2}=1$

$\therefore M=-\frac{K_{1}}{4 L_{0}}+\sqrt{\left(\frac{K_{1}}{4 L_{0}}\right)^{2}+\frac{K_{1}}{L_{0}}\left(1-\frac{S}{2}\right)}$

c) $K_{2}=\frac{S^{4}}{M^{2}} L_{0}^{2}$

d) $\mathrm{EDC}: 48.6 \mathrm{wt} \%$, TCE : $51.4 \mathrm{wt} \%$.

化させても分析値に大きな変化がないことからも明らかである。 一方, 3.1 .4 に拈いてホルムアルデヒド, $\mathrm{SO}_{3}$ についての物質収 支が満足されて括り，最大 GAM 収率 $188.5 \%$ を得ている。した がって, MS とホルムアルデヒド, $\mathrm{SO}_{3}$ 間の平衡のため, 反応の 進行とともに MS が再生されると考えられる。

すなわち MS は熱溶媒下に拈いてつぎのような状態にある。

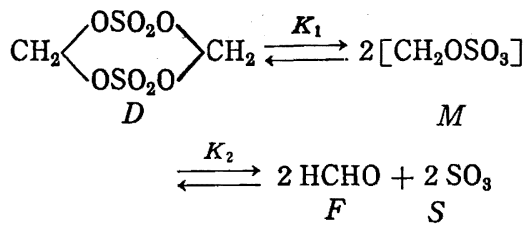

ただし，

$d_{0}$ =初充テン $\mathrm{MS}$ 二量体 $(\mathrm{mol})$

$M=\frac{m}{d_{0}}(m: \mathrm{MS}$ 単量体 $\mathrm{mol})$

$S=\frac{S}{d_{0}}\left(S: \mathrm{SO}_{3} \mathrm{~mol}\right)$

$D=\frac{d}{d_{0}}(d:$ 熱溶媒下での $\mathrm{MS}$ 二量体 $\mathrm{mol})$

$F=\frac{f}{d_{0}}(f:$ ホルムアルデヒド $\mathrm{mol})$

$K_{1}, K_{2}$ : 平衡定数

以上から下記の平衡式 (1)，(2)，(3) および物質収支式 (4) が誘導される。(1) 式から表 4 最後列に示す $K_{1}$ が得られ，(2), (3)，（4)式から表 5 最後列の $K_{2}$ が得られる。

$$
\begin{aligned}
& K_{1}=\frac{M^{2}}{D} L_{0} \\
& K_{2}=\frac{S^{2} F^{2}}{M^{2}} L_{0}^{2} \\
& S=F \\
& D+1 / 2 M+1 / 2 F=1
\end{aligned}
$$

ベソゼン，DMSO 中での異なった温度に拈ける $K_{1}$ の測定值 からこの反応熱は $6.09 \mathrm{kcal} \cdot \mathrm{mol}^{-1}$ と算出され, 反応温度 $80^{\circ} \mathrm{C}$ に和ける $K_{1}$ は $1.22 \times 10^{-2}$ と計算された。以下の解析に括いて は， $K_{1}$ として $1.22 \times 10^{-2} ， K_{2}$ として EDC 中に特ける実測平均 値 $5.6 \times 10^{-3}$ を使用する。

\section{2 反応機構ならびに速度式}

4.1 で明らかとなった MS の予備平衡を考慮してつぎの反応機
構を仮定する。

$$
\begin{aligned}
& \underset{D}{\mathrm{CH}_{2}\left\langle\underset{\mathrm{OSO}_{2} \mathrm{O}}{\mathrm{OSO}_{2} \mathrm{O}}\right\rangle \mathrm{CH}_{2} \stackrel{K_{1}}{\rightleftarrows} 2\left[\mathrm{CH}_{2} \mathrm{OSO}_{3}\right]} \\
& \stackrel{K_{2}}{\rightleftarrows} \underset{F}{2} \underset{S}{\mathrm{HCHO}}(d)+2 \underset{\mathrm{SO}_{3}(d)}{\stackrel{M}{\rightleftarrows}} \\
& \begin{array}{rc}
{\left[\mathrm{CH}_{2} \mathrm{OSO}_{3}\right]+\mathrm{CO}(d) \stackrel{k}{\uparrow} \underset{\left[\mathrm{CH}_{2}(\mathrm{CO}) \mathrm{OSO}_{3}\right]}{A}} \\
P_{\mathrm{CO}} & A
\end{array} \\
& {\left[\mathrm{CH}_{2}(\mathrm{CO}) \mathrm{OSO}_{3}\right]+\mathrm{CH}_{3} \mathrm{OH} \stackrel{\text { 系外 }}{\longrightarrow} \mathrm{CH}_{2}(\mathrm{OH}) \mathrm{COOCH}_{3}}
\end{aligned}
$$

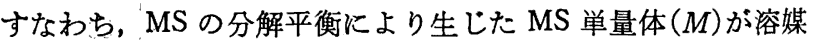
中の一酸化炭素と反応し $(A)$ を生成する。 $(A)$ は系外でメチル エステル化（III）を受け GAM (G) を生成する。

ここで (II)の速度定数を $k$, 一酸化炭素の溶解に関する Henry 定数を $H^{\mathrm{CO}}$ とすると速度式は以下のように誘導される。（I）で 示される MS の平衡関係から前に述べた（1),(2), (3) が導か れ，これをホルムアルデヒドの物質収支式に代入し（5）式を得 る。（5）式において $L_{0} M^{2} / K_{1}$ は最大実験濃度において (5) 式 左辺に対し 9.5\%であるのでこれを無視すると, MS 単量体濃度 $M$ は式（6）で求められる。したがって速度式として（7）式を 得る。

$$
\begin{aligned}
& \frac{L_{0}}{K_{1}} M^{2}+\frac{1}{2} M+\frac{1}{2} \sqrt{\frac{M}{L_{0}}} K_{2}^{1 / 4}+\frac{1}{2} G=1 \\
& M=\left(2+\frac{\sqrt{K_{2}}}{2 L_{0}}-G\right)-\sqrt{\left(2+\frac{\sqrt{K_{2}}}{2 L_{0}}-G\right)^{2}-(2-G)^{2}} \\
& v \equiv \frac{\mathrm{d} G}{\mathrm{~d} t}=k H^{\mathrm{CO}} P_{\mathrm{CO}} M=k H^{\mathrm{CO}} P_{\mathrm{CO}}\left\{\left(2+\frac{\sqrt{K_{2}}}{2 L_{0}}-G\right)\right. \\
& \left.-\sqrt{\left(2+\frac{\sqrt{K_{2}}}{2 L_{0}}-G\right)^{2}-(2-G)^{2}}\right\} \\
& \text { ただし，G=生成 GAM (mol) }
\end{aligned}
$$

\section{3 初速度による解析}

初速度すなわち $t=0$ では（7）式において， $G=0$ であり, 速 度定数を $k_{0}$ とすると, 初速度式として（8）式を得る。

$$
\begin{aligned}
v_{0}= & k_{0} H^{\mathrm{CO}} P_{\mathrm{CO}} M_{0}=k_{0} H^{\mathrm{Co}} P_{\mathrm{CO}} \\
& \times\left\{\left(2+\frac{\sqrt{K_{2}}}{2 L_{0}}\right)-\sqrt{\left(2+\frac{\sqrt{ } K_{2}}{2 L_{0}}\right)^{2}-4}\right\}
\end{aligned}
$$


Table 6 The determination of the initial velocity

Conditions

\begin{tabular}{|c|c|c|c|c|c|}
\hline \multirow{3}{*}{$\begin{array}{l}\text { Temp. } \\
\left({ }^{\circ} \mathrm{C}\right)\end{array}$} & \multirow{3}{*}{${ }_{\left(\mathrm{kg} \cdot \mathrm{cm}^{-2}\right)}^{P_{\mathrm{CO}}}$} & \multirow{3}{*}{$L_{0} \times 10^{2}$} & \\
\hline & & & \multicolumn{2}{|c|}{ Exp. eq. ${ }^{a}$ ) } & \multirow{2}{*}{$\begin{array}{c}v_{0}^{b)} \\
\times 10^{2}\end{array}$} \\
\hline & & & $\bar{a}$ & $b$ & \\
\hline \multirow{4}{*}{80} & 49 & 1.05 & 0.55 & 12.0 & 8.34 \\
\hline & 29 & 1.05 & 0.45 & 22.2 & 4.50 \\
\hline & 19 & 1.05 & 0.45 & 33.0 & 3.03 \\
\hline & 9 & 1.05 & 0.40 & 64.5 & 1.55 \\
\hline \multirow{3}{*}{80} & 29 & 0.698 & 0.54 & 31.2 & 3.21 \\
\hline & 29 & 0.348 & 0.55 & 62.1 & 1.61 \\
\hline & 29 & 0.160 & 0.50 & 85.9 & 0.91 \\
\hline 90 & 29 & 1.05 & 0.54 & 8.10 & 12,3 \\
\hline 70 & 29 & 1.05 & 0.68 & 85.9 & 1.16 \\
\hline
\end{tabular}

a) Exp. eq. of initial rate, $y=\frac{t}{a t+b}, \quad t: \min$, $y$ : GAM (mol)/Charge MS (mol), $a, b$ : Const.

b) $v_{0}=\left(\frac{\mathrm{d} y}{\mathrm{~d} t}\right)_{0}=\frac{1}{b}$

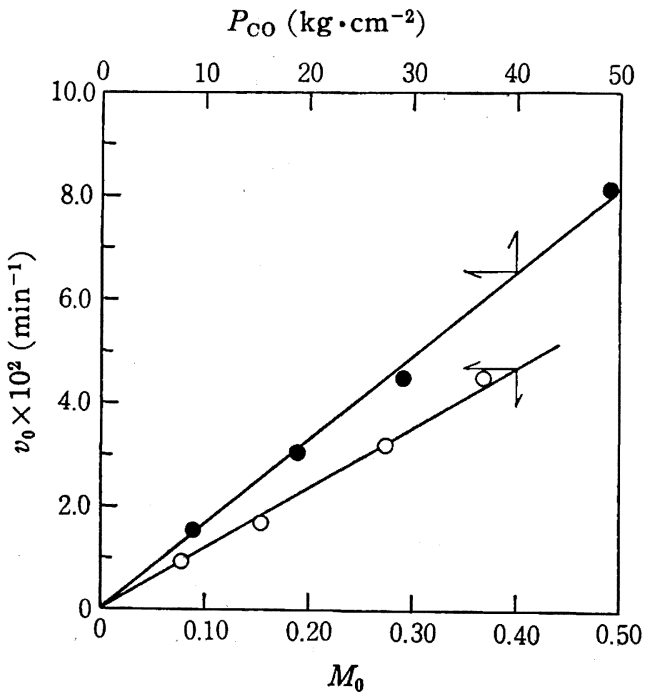

Fig. 5 Relationship between initial velocity and $\mathrm{CO}$ pressure or initial conc. of MS monomer

（8）式から MS 初濃度 $L_{0}$ が一定ならば, 初速度 $v_{0}$ は一酸化 炭素圧に比例し，一酸化炭素圧 $P_{\mathrm{CO}}$ が一定ならば，MS 単量体 初濃度 $M_{0}$ に比例するはずである。図 $2,3,4$ の実験結果を $y=$ $t /(a t+b)(y=G, t:$ 反応時間 (min), $a, b:$ 定数）なる実験式で 表現し, 実験式の $t=0$ に拈ける微係数 $(1 / b)$ により初速度を求 め（表 6) これを $P_{\mathrm{CO}}$ と $M_{0}$ に対してプロットして図 5 を得た。 $v_{0}$ と $P_{\mathrm{CO}}, v_{0}$ と $M_{0}$ の間には直線関係が認められ，招の括のの直 線の傾きから（9），(10）式の数値が得られた。

$$
\begin{aligned}
& \frac{v_{0}}{P_{\mathrm{CO}}}=k_{0} H_{\mathrm{EDC}}^{\mathrm{CO}} M_{0}=0.0016 \\
& \frac{v_{0}}{M_{0}}=k_{0} H_{\mathrm{EDC}}^{\mathrm{CO}} P_{\mathrm{CO}}=0.115
\end{aligned}
$$

(9)，(10)式から $k_{0}$ を算出すると，それぞれ $6.28 ， 5.85 \mathrm{~min}^{-1}$ とほほ一致した数値となり，（8）式は実験結果を満足に表現して おり, 本反応の $\mathrm{EDC}$ 溶媒下, $80^{\circ} \mathrm{C}$ に打ける初速度の解析から得 た速度定数は $k_{0}=6.05 \mathrm{~min}^{-1}$ であった。

また反応系内にホルムアルデヒドまたは $\mathrm{SO}_{3}$ を添加すると（I） の平衡が移動し, MS 単量体初濃度が変化して初速度に影響を与 えることが期待される。このことを確認するために 2.2 で述べた

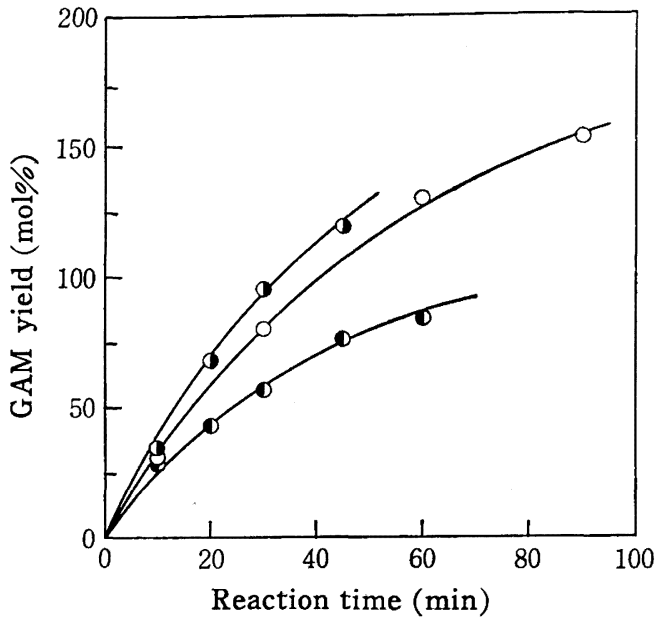

Fig. 6 Effect of added formaldehyde and $\mathrm{SO}_{3}$

Temp. $=80^{\circ} \mathrm{C}, P_{\mathrm{CO}}=29 \mathrm{~kg} \cdot \mathrm{cm}^{-2}$

$L_{0} \times 10^{3}$

$$
\begin{aligned}
& \bigcirc: 5.19, \bigcirc: 5.40, \Phi: 5.80 \\
B= & \left(\beta / d_{0}\right)- \\
& \bigcirc: 0.602 \text { (formaldehyde), } \\
& \bigcirc: 0.824\left(\mathrm{SO}_{3}\right), \quad \square: 0.191\left(\mathrm{SO}_{3}\right)
\end{aligned}
$$

$\mathrm{EDC}-\mathrm{HCHO}, \mathrm{EDC} \mathrm{SO}_{3}$ 溶媒を調整し, MS を加えて一酸化炭素 と反応させ図 6 を得た。

添加したホルムアルデヒドまたは $\mathrm{SO}_{3}$ のモル数を $\beta, \beta / d_{0}=B$, $\mathrm{MS}$ 単量体初濃度を $M_{0}^{\prime}$ とすると, (2) 式に $F+B$ または $S+B$ を代入することにより $M_{0}^{\prime}$ は（11）式で与えられ, 初速度 $v_{0}^{\prime}$ は (12）式となる。

$$
\begin{aligned}
M_{0}^{\prime}= & 2+\frac{B}{2}+\frac{\sqrt{K_{2}}}{2 L_{0}}-\sqrt{\left(2+\frac{B}{2}+\frac{\sqrt{K_{2}}}{2 L_{0}}\right)^{2}-2(2+B)} \\
v_{0}^{\prime}= & k H_{\mathrm{EDC}}^{\mathrm{CO}} P_{\mathrm{CO}}\left\{\left(2+\frac{B}{2}+\frac{\sqrt{K_{2}}}{2 L_{0}}\right)\right. \\
& \left.-\sqrt{\left(2+\frac{B}{2}+\frac{\sqrt{K_{2}}}{2 L_{0}}\right)^{2}-2(2+B)}\right\}
\end{aligned}
$$

図6 の結果を $y=t /(a t+b)$ なる実験式で表現し， $t=0$ の微係 数により実測初速度 $v_{0}^{\prime \prime}$ を求め, 理論初速度 $v_{0}^{\prime}$ と比較したのが 表 7 である。 $v_{0}{ }^{\prime}$ と $v_{0}{ }^{\prime \prime}$ は $2 \%$ 以内で一致しており，この面から も前に述べた反応機構が満足されていることが明らかとなった。

\section{4 皘分式による解析}

（6）式において根号内を Taylor 搌開により第 3 項までとる と, 実験範囲内に扎いて第 4 項は第 3 項の $6 \%$ 以となり，第 4 項以下を無視すると、つぎの（13）式を得る。これを（7) 式に代 入し Taylor 展開すると, 第 3 項は第 2 項の $3 \%$ ので，第 3 項以下を無視すると（14）式となり（14）式を積分する ことにより（15）式が得られる。

$$
\begin{aligned}
& M \fallingdotseq \frac{(2-G)^{2}}{2\left(2+\frac{\sqrt{K_{2}}}{2 L_{0}}-G\right)}+\frac{(2-G)^{4}}{8\left(2+\frac{\sqrt{K_{2}}}{2 L_{0}}-G\right)^{3}} \\
& k H^{\mathrm{co}} P_{\mathrm{CO}} \mathrm{d} t=\frac{\mathrm{d} G}{M} \fallingdotseq\left\{\frac{2}{2-G}+\frac{\frac{\sqrt{K_{2}}}{(2-G)^{2}}}{2\left(2+\frac{\sqrt{L_{2}}}{2 L_{0}}-G\right)}\right\} \mathrm{d} G
\end{aligned}
$$


Table 7 Experimental results on added compounds

Conditions

\begin{tabular}{|c|c|c|c|c|c|c|c|c|}
\hline \multicolumn{5}{|c|}{ 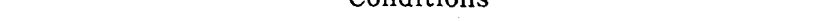 } & & \multirow{2}{*}{$\begin{array}{l}v_{0}{ }^{\prime \prime b)} \\
\times 10^{2}\end{array}$} & \multirow{2}{*}{$\begin{array}{c}\text { Error }^{c)} \\
(\%)\end{array}$} \\
\hline Added compound & $\begin{array}{c}L_{0} \\
\times 10^{9}\end{array}$ & $\begin{array}{c}P_{\mathrm{CO}} \\
\left(\mathrm{kg} \cdot \mathrm{cm}^{-2}\right)\end{array}$ & $\begin{array}{c}\text { Temp. } \\
\left({ }^{\circ} \mathrm{C}\right)\end{array}$ & $B^{a)}$ & $M_{0}^{\prime}$ & $\begin{array}{l}v_{0}^{\prime \prime} \\
\times 10^{2}\end{array}$ & & \\
\hline Formaldehyde & 5.19 & 29 & 80 & 0.602 & 0.275 & 3.28 & 3.28 & 0 \\
\hline \multirow{2}{*}{$\mathrm{SO}_{3}$} & 5.80 & 29 & 80 & 0.191 & 0.258 & 3.08 & 3.03 & +1.62 \\
\hline & 5.40 & 29 & 80 & 0.824 & 0.305 & 3.64 & 3.57 & -1.92 \\
\hline
\end{tabular}

a) $B=\frac{\beta}{d_{0}} \quad \beta$ : Added formaldehyde (or $\left.\mathrm{SO}_{3}\right)(\mathrm{mol})$.

b) Observed.

c) Error $=\frac{v_{0}{ }^{\prime}-v_{0}^{\prime \prime}}{v_{0}{ }^{\prime}} \times 10^{2}$

Table 8 The determination of the velocity constant

Conditions

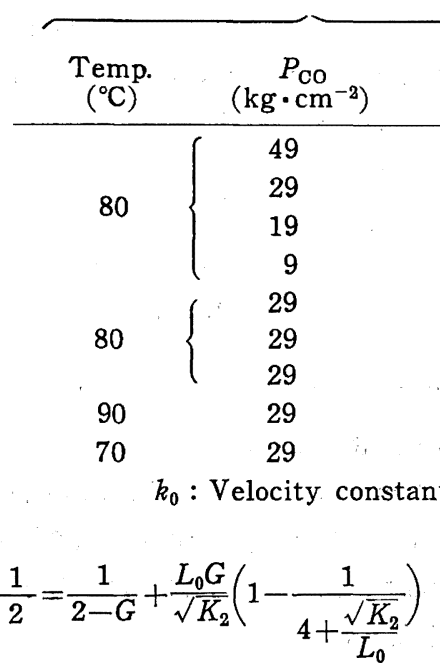

図 2，3，4 の実験結果を(15) 式に代入し，積分法による $k$ と して表 8 の結果を得た。これらは初速度から求めた各温度に扣け る $k_{0}$ と比較してる数パーセント以内で一致して括り, 前に述べ た反応機構に基つく積分式（15）も実験結果を満足に説明してい る。また（15）式から求めた $90,80,70^{\circ} \mathrm{C}$ における速度定数 は, Arrhenius 式を満足している（図 7 )。また四 7 から一酸化 炭素の溶解熱, MS 単量体, ホルムアルデヒド, $\mathrm{SO}_{3}$ 間の分解熱 ‘を含む見かけの活性化エネルギーは $28.4 \mathrm{kcal} \cdot \mathrm{mol}^{-1}$ であった。

\section{5 溶媒効果}

以上の速度論による検討から, 本反応は MS 単量体と一酸化炭

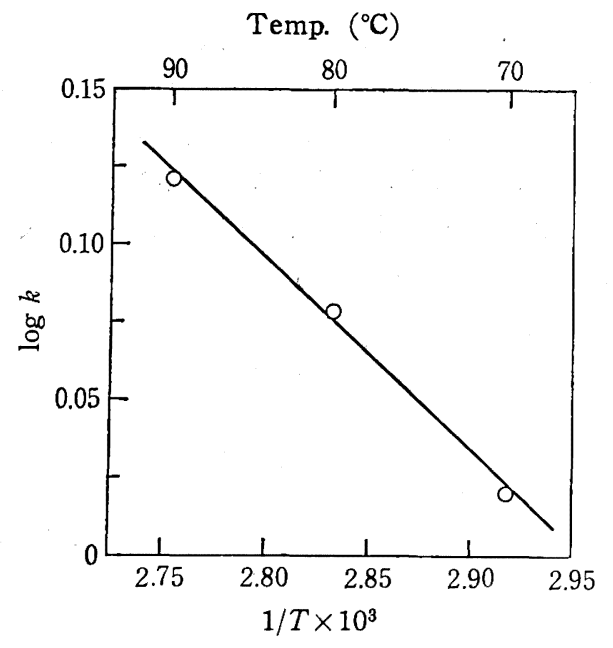

Fig. 7 Temperature coefficient of the velocity constant

$$
\frac{k H^{\mathrm{CO}} P_{\mathrm{CO}} L_{0}}{\sqrt{\overline{K_{2}}}} t+\frac{1}{2}=\frac{1}{2-G}+\frac{L_{0} G}{\sqrt{K_{2}}}\left(1-\frac{1}{4+\frac{\sqrt{K_{2}}}{L_{0}}}\right)
$$

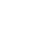

Calculations

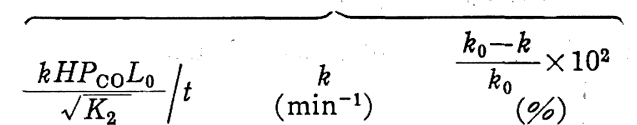

\begin{tabular}{lcc}
$\sqrt{K_{2}}$ & $\left(\mathrm{~min}^{-1}\right)$ & $(\%)$ \\
\hline 0.0275 & 5.94 & -1.82 \\
0.0170 & 6.21 & +2.66 \\
0.0112 & 6.24 & +3.07 \\
0.0052 & 6.12 & +1.16 \\
0.0104 & 5.71 & -5.62 \\
0.0054 & 6.17 & +1.98 \\
0.00265 & 6.35 & +4.96 \\
0.0433 & 15.82 & +6.78 \\
0.0044 & 1.61 & -0.63
\end{tabular}


Table 9 Experimental results on solvent effect

Conditions

\begin{tabular}{cccccr}
\hline Solvent $(\mathrm{wt} \%)$ & $\begin{array}{c}\mathrm{Temp}^{\mathrm{Temp}} \\
\left({ }^{\circ} \mathrm{C}\right)\end{array}$ & $\begin{array}{c}P_{\mathrm{CO}} \\
\left(\mathrm{kg} \cdot \mathrm{cm}^{-2}\right)\end{array}$ & $\begin{array}{c}H \\
\left(\mathrm{~kg}^{-1} \cdot \mathrm{cm}^{2}\right)\end{array}$ & $\begin{array}{c}L_{0} \\
\times 10^{2}\end{array}$ \\
\hline 100 & 0 & 80 & 29 & $6.8 \times 10^{-4}$ & 10.5 \\
77.8 & 22.2 & 80 & 29 & $7.03 \times 10^{-4}$ & 5.97 \\
60.8 & 39.2 & 80 & 29 & $7.24 \times 10^{-4}$ & 6.25
\end{tabular}

Calculations

\begin{tabular}{|c|c|c|}
\hline$\frac{k H^{\mathrm{CO}} P_{\mathrm{CO}} L_{0}}{\sqrt{\overline{K_{2}}}} / t$ & $\begin{array}{c}k \\
\left(\min ^{-1}\right)\end{array}$ & $\varepsilon$ \\
\hline 17.0 & 6.21 & 10.36 \\
\hline 6.40 & 3.98 & 8.82 \\
\hline 4.65 & 2.68 & 7.52 \\
\hline
\end{tabular}

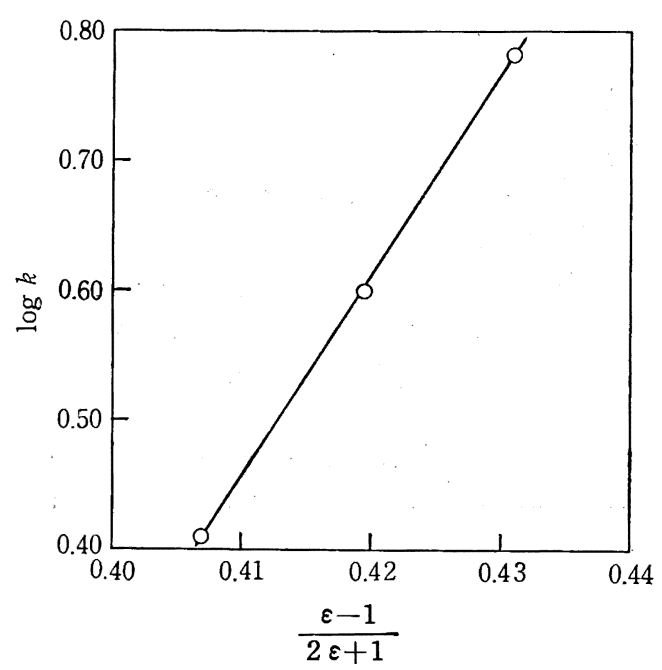

Fig. 9 Examination of experimental solvent effect by the Kirkwood equation

る変化を無視した。また，EDC-TCE 混合系への一酸化炭素の溶 解に対する Henry 定数は, 図 1 の各単一溶媒に対する值を用い モル分率により算出した。混合溶媒の誘電率については Onsagar 式 $(16)^{5)}$ おび EDC, TCE に対する文献值 $\left.{ }^{6}\right) 10.36 ， 2.30$ を用 いて算出した。

これらの数値を使用し，図8の結果を積分式（15）により解析 し速度定数を求めた(表 9 )。

$\frac{\left(\varepsilon-\varepsilon_{\mathrm{a}}\right)\left(2 \varepsilon_{\mathrm{a}} \varepsilon+n_{\mathrm{a}}^{4}\right)}{\varepsilon_{\mathrm{a}}\left(2 \varepsilon+n_{\mathrm{a}}^{2}\right)^{2}} \frac{w_{\mathrm{a}}}{\rho_{\mathrm{a}}}+\frac{\left(\varepsilon-\varepsilon_{\mathrm{b}}\right)\left(2 \varepsilon_{\mathrm{b}} \varepsilon+n_{\mathrm{b}}^{4}\right)}{\varepsilon_{\mathrm{b}}\left(2 \varepsilon+n_{\mathrm{b}}^{2}\right)^{2}} \frac{w_{\mathrm{b}}}{\rho_{\mathrm{b}}}=0$

5) L. Onsagar, J. Amer. Chem. Soc., 58, 1486(1936).

6) J. A. Riddick, W. B. Bunger, "Techniques of chemistry", John Wiley \& Sons, Inc., New York (1970) Vol. II, p. 355,372 . $w_{1}$ : 重量分密, $n_{1}$ : 屈折率, $\rho_{1}$ : 密度, $\varepsilon_{1}$ : 誘電率.

$$
\ln \frac{k}{k_{\mathrm{A}}}=-\frac{1}{k T} \cdot \frac{\varepsilon-1}{2 \varepsilon+1}\left(\frac{\mu_{\mathrm{CO}}{ }^{2}}{r_{\mathrm{CO}^{3}}}+\frac{\mu_{\mathrm{MS}}{ }^{2}}{r_{\mathrm{MS}^{3}}}-\frac{\mu_{\neq}^{2}}{r_{\neq}{ }^{8}}\right)
$$

$k_{\mathrm{A}}:$ 真空中に打ける速度定数

$r:$ 分子半径

$\boldsymbol{k}:$ Boltzmann 定数

$\mu:$ 分子の双極子モーメント

表 9 で得られた速度定数と（16）式で求めた誘電率との関係を 非静電項を無視した双極子間二分子反応に関する Kirkwood 式7) （17）により検討し図 9 を得た。

因 9 から明らかなよらに $\log k$ と $(\varepsilon-1) /(2 \varepsilon+1)$ との間には 正の直線関係が認められ（17）式にしたがうことから，本反応は MS 単量体と一酸化炭素との二つの多極子間の二分子反応により 進行することが推定される。

\section{5 総 括}

硫酸メチレン（またはホルムアルデヒドと $\mathrm{SO}_{3}$ ） と一酸化炭素 とを原料としてグリコール酸を温和な条件下で円滑に合成でき， その機構は硫酸メチレン単量体と一酸化炭素との双極子間反応に よるすのであることを明らかにした。

本反応を有利に進行させるには, 硫酸メチレン, ホルムアルデヒ ド括よび $\mathrm{SO}_{3}$ に対する溶解度が大きく，かつ反応中間体の安定化 に寄与する極性の高い溶媒，たとえば硫酸などの無機酸や EDC などの有機溶媒が適当であるが，単に反応のみならず生成物分離 法ともあわせ検討を行なう必要があり, 以後研究を進めてゆく予 定である。

（1973 年 10 月，第 15 回高圧討論会発表）

7) J. G. Kirkwood, J. Chem. Phys., 2, 351(1934).

\title{
Kinetic Study on the Synthesis of Methyl Glycolate from Methylene
}

\section{Sulfate and Carbon-Monoxide under Pressure}

\author{
Akira Yanagase, Nobuyuki Sugita, Kiyoshi Kudo \\ and Yoshimasa TAKEzAKI \\ The Institute for Chemical Research, Kyoto University; \\ Gokanosho, Uji-shi 611 Japan
}

Synthesis of methyl glycolate from methylene sulfate and carbon-monoxide has been studied kinetically under pressure in 1,2-dichloroethane (EDC) solution. The rate of methyl glycolate formation is of the first order with respect to carbon-monoxide pressure and nearly of the first order to the concentration of methylene sulfate. Under the reaction conditions studied, dimeric methylene sulfate decomposes to its monomer, formaldehyde and $\mathrm{SO}_{3}$ in equilibrium.

Based on these results, the following mechanism has been proposed : methylene sulfate monomer reacts with carbon monoxide to form a complex which is converted into methyl glycolate by 
the action of methanol outside of the reaction system.

$$
\begin{aligned}
& \mathrm{CH}_{\mathrm{CHO}_{2}-\mathrm{O}}^{\mathrm{O}-\mathrm{SO}_{2}-\mathrm{O}} \mathrm{CH}_{2} \stackrel{K_{1}}{\rightleftarrows} 2\left[\mathrm{CH}_{2} \mathrm{OSO}_{3}\right] \stackrel{K_{2}}{\rightleftarrows} 2 \mathrm{HCHO}+2 \mathrm{SO}_{3} \\
& {\left[\mathrm{CH}_{2} \mathrm{OSO}_{3}\right]+\mathrm{CO}(d) \stackrel{k}{\longrightarrow}\left[\mathrm{CH}_{2}(\mathrm{CO}) \mathrm{OSO}_{3}\right]} \\
& {\left[\mathrm{CH}_{2}(\mathrm{CO}) \mathrm{OSO}_{3}\right]+2 \mathrm{CH}_{3} \mathrm{OH} \longrightarrow \mathrm{CH}_{2}(\mathrm{OH}) \mathrm{COOCH}_{3}+\mathrm{CH}_{3} \mathrm{OSO}_{3} \mathrm{H}}
\end{aligned}
$$

The derived rate equation is :

$$
\begin{aligned}
& v_{0}=k H P_{\mathrm{CO}}\left\{\left(2+\frac{\sqrt{K_{2}}}{2 L_{0}}\right)-\sqrt{\left(2+\frac{\sqrt{K_{2}}}{2 L_{0}}\right)^{2}-4}\right\} \\
& \frac{k H P_{\mathrm{CO}} L_{0}}{\sqrt{K_{2}}} t+\frac{1}{2}=\frac{1}{2-G}+\frac{L_{0}}{\sqrt{K_{2}}} G\left(1-\frac{1}{4+\frac{\sqrt{K_{2}}}{L_{0}}}\right)
\end{aligned}
$$

$H:$ Henry constant of $\mathrm{CO}, P_{\mathrm{CO}}: \mathrm{CO}$ pressure $\left(\mathrm{kg} \cdot \mathrm{cm}^{-2}\right), \quad L_{0}:$ Initial charge of MS $(\mathrm{mol}) /$ solvent $(\mathrm{mol}), G:$ GAM $(\mathrm{mol}) /$ Initial charge of MS (mol),

which is reasonably in agreement with the experimental results. The equilibrium constants, rate constants, Henry constant in EDC and the overall activation energy have been determined to be $K_{1}=1.22 \times 10^{-2}, K_{2}=5.7 \times 10^{-3}, k=6.05 \mathrm{~min}^{-1}, H_{\mathrm{EDC}}^{\mathrm{CO}}=6.8 \times 10^{-4} \mathrm{~kg}^{-1} \cdot \mathrm{cm}^{2}$ and $E_{\mathrm{a}}=28.4$ $\mathrm{kcal} \cdot \mathrm{mol}^{-1}$, respectively.

In the detailed experiment by changing dielectric constant of medium, the observed rate constant has been found to fit the Kirkwood modified relation, which holds for the reaction through dipole-dipole interaction. 